\title{
PENGARUH PENYIMPANAN BEKU TERHADAP KARAKTERISTIK KIMIA DAN FISIK Caulerpa racemosa, DRIP, DAN FILTRATNYA
}

\section{Effect of Frozen Storage on the Chemical and Physical Characteristics of Caulerpa racemosa, Drip, and its Filtrate}

\author{
Nurhayati, Dina Fransiska, dan Agusman \\ Balai Besar Riset Pengolahan Produk dan Bioteknologi Kelautan dan Perikanan, \\ JI. KS Tubun, Petamburan VI, Jakarta Pusat, DKI Jakarta, 10260, Indonesia \\ *Korespondensi penulis : enhaitie@gmail.com \\ Diterima: 19 Februari 2021; Direvisi: 29 Mei 2021; Disetujui: 25 Agustus 2021
}

\begin{abstract}
ABSTRAK
Caulerpa racemosa merupakan rumput laut hijau dengan kandungan air yang tinggi sehingga mudah mengalami kerusakan. Penyimpanan dalam suhu beku merupakan salah satu cara untuk memperpanjang masa simpan suatu produk. Namun, pembekuan produk juga dapat menyebabkan terjadinya berbagai perubahan yang tidak dikehendaki. Penelitian ini bertujuan untuk menganalisis pengaruh penyimpanan pada suhu beku terhadap karakteristik kimia dan fisik C. racemosa, drip, dan filtrat yang dihasilkan. Sampel berupa C. rasemosa disimpan dalam ruangan penyimpan beku (cold storage) dan diamati setiap minggunya hingga minggu ke-4. Parameter uji yang diamati meliputi rendemen, komposisi proksimat, kadar garam, uji warna $\left(L^{*}\right.$, $\left.a^{*}, b^{*}\right)$, dan viskositas, masing-masing pada $C$. racemosa yang ditiriskan, drip, dan filtrat $C$. racemosa. Hasil penelitian menunjukkan bahwa penyimpanan beku $C$. racemosa dapat mengurangi berat pada sampel akhir karena sebagian besar drip keluar setelah pelelehan/ thawing, yaitu sekitar $77,88-84,81 \%$. Karakteristik fisik maupun kimia C. racemosa yang disimpan selama 1 hingga 4 minggu tidak berbeda nyata antar waktu penyimpanan, namun berbeda nyata pada C. racemosa tanpa disimpan beku, yaitu pada kadar air, abu, dan garam.
\end{abstract}

KATA KUNCI : Caulerpa racemosa, rumput laut hijau, filtrat Caulerpa, penyimpanan beku

\begin{abstract}
Caulerpa racemosa is a green seaweed that has a high moisture content, so it is easily damaged. Frozen storage is one way to extend the shelf life of a product. However, freezing the product can cause various undesirable changes to occur. This study was aimed to analyze the effect of storage at freezing temperature on the chemical and physical characteristics of $\underline{C}$.

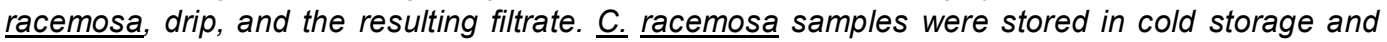
observed every week until the $4^{\text {th }}$ week. The test parameters observed were yield, proximate composition, salt content, color $\left(L^{*}, a^{*}, b^{*}\right)$, and viscosity on drained $\underline{C}$. racemosa, drip, and $\underline{C}$. racemosa filtrate. The results showed that frozen storage of $\underline{C}$. racemosa could cause weight loss in the final sample because most of the drip came out after thawing, which was around 77.88 $84.81 \%$. Physical and chemical characteristics of $\underline{C}$. racemosa stored for 1 to 4 weeks were not significantly different from unfrozen $\underline{C}$. racemosa, i.e. water, ash, and salt content.
\end{abstract}

KEYWORDS: Caulerpa racemosa, green seaweed, Caulerpa filtrate, frozen storage

\section{PENDAHULUAN}

Caulerpa racemosa merupakan salah satu jenis rumput laut hijau dari famili Caulerpaceae. C. racemosa memiliki ramuli berbentuk bulatan-bulatan seperti buah anggur, sehingga sering disebut dengan anggur laut atau sea grape (Yudasmara, 2015). Daerah sebaran $C$. racemosa mencakup perairan tropis dan subtropis dengan keanekaragaman paling besar berada di daerah tropis (Hao et al., 2019). C. racemosa banyak digemari masyarakat pesisir karena memiliki rasa yang khas dan gurih serta tekstur yang lembut. Masyarakat biasa mengonsumsi $C$. racemosa dalam bentuk mentah sebagai urap, lalapan, atau sayuran segar (Fithriani, 2015; Pereira, 2011).

Penelitian dasar mengenai karakteristik kimia dan fungsional C. racemosa telah banyak dilakukan (Hong, Hien, \& Son, 2007; Kumar, Gupta, Kumari, Reddy, \& Jha, 2011; Ma'ruf, Ibrahim, Dewi, Susanto, \& Amalia, 
2013; Sanjaya, Widjanarko, \& Setijawati, 2016). Ditinjau dari segi pemanfaatannya, C. racemosa dapat digunakan dalam bentuk utuh, tepung maupun filtratnya. Putri (2020) membuat biskuit fungsional dari tepung $C$. racemosa yang kaya serat, vitamin, dan mineral. Sementara itu, Agusman, Murdinah, dan Wahyuni (2020) melaporkan bahwa mi yang dibuat dengan penambahan filtrat $C$. racemosa mengandung $\beta$-karoten, mineral, dan total fenol yang lebih tinggi dibandingkan mi tanpa filtrat C. racemosa. Selain itu, Murdinah, Subaryono, Wahyuni, dan Nurhayati (2020) juga menggunakan filtrat $C$. racemosa pada pembuatan saus, yang menghasilkan saus dengan aroma dan citarasa yang khas serta mengandung antioksidan yang tinggi.

C. racemosa mudah sekali mengalami penurunan kualitas dan mengalami kerusakan dalam waktu beberapa hari setelah proses pemanenan. Hal ini mengakibatkan jangkauan pemasaran komoditas tersebut menjadi terbatas (Anwar, Bubun, \& Rosmawati, 2016). Potensi kerusakan C. racemosa disebabkan karena kandungan air yang tinggi, sekitar 90\% (Sedjati, 1999), namun mudah sekali keluar dari talusnya setelah dilakukan pemanenan. Rumput laut segar yang bersifat mudah rusak tersebut dapat diolah sehingga dapat memaksimalkan pemanfaatannya (Siah, Aminah, \& Ishak, 2014). Penyimpanan pascapanen merupakan salah satu cara untuk mencegah penurunan kualitas bahan pangan.

Salah satu teknik penyimpanan yang dapat memperpanjang umur simpan suatu bahan pangan adalah pembekuan. Pada suhu beku, air dalam bahan pangan berubah wujud dari fase cair ke fase padat dengan membentuk kristal es, menyebabkan menurunnya aktivitas air, sehingga menghambat kecepatan reaksi metabolisme (Wills, Lee, Graham, McGlasson, \& Hall, 1981 dalam Safaryani, Haryanti, \& Hastuti, 2007). Namun, penyimpanan beku dapat menurunkan kualitas produk, seperti berkurangnya kandungan nutrisi, terjadinya perubahan warna dan tekstur, serta terbentuknya drip pada produk hasil thawing yang berpengaruh pada pengurangan berat produk (van der Sman, 2020). Hingga saat ini belum ada penelitian mengenai pengaruh penyimpanan beku C. racemosa dan potensi kehilangan nutrisinya selama penyimpanan. Penelitian ini bertujuan untuk menganalisis pengaruh penyimpanan pada suhu beku terhadap karakteristik kimia dan fisik C. racemosa, drip, dan filtrat yang dihasilkan.

\section{BAHAN DAN METODE}

\section{Bahan}

Bahan utama penelitian adalah Caulerpa racemosa yang diperoleh dari perairan Binuangeun,
Banten (650.708' LS; $105^{\circ} 52.815^{\prime}$ BT). C. racemosa dicuci dengan air laut dan disortasi dari kotoran dan rumput laut jenis lain. Selanjutnya sampel dikemas ke dalam plastik klip dengan berat satu kilogram per kemasan, lalu dibawa ke Balai Besar Riset Pengolahan Produk dan Bioteknologi Kelautan dan Perikanan (BBRP2BKP) di Jakarta menggunakan coolbox disertai es curai. Bahan lain yang digunakan untuk analisis diantaranya $\mathrm{NaOH}$ (Merck), asam borat (Merck), $\mathrm{HCl}$ (Merck), metanol (Merck), Bromocresol green/BCG (Merck), methylene red, $\mathrm{H}_{2} \mathrm{SO}_{4}$ (Merck), tablet kjeltab, dan dietil eter (Smartlab).

\section{Metode}

Setelah sampai di laboratorium, sampel segera dimasukkan ke dalam ruang penyimpan beku (cold storage) suhu $-18 \pm 2^{\circ} \mathrm{C}$. C. racemosa yang telah disimpan beku dikeluarkan dari cold storage, kemudian di-thawing dengan cara diletakkan di dalam wadah dan dialiri air sampai semua es mencair. Sampel dikeluarkan dari kemasan plastik dan ditiriskan, lalu drip (cairan yang keluar dari talus dan ramuli $C$. racemosa setelah dilakukan thawing) digabung, baik yang tertampung di dalam kemasan plastik maupun dari hasil penirisan. Sampel yang telah ditiriskan tersebut diambil filtratnya menggunakan slow juicer (Philips HR1855). Pengamatan dilakukan setiap 1 minggu sekali selama 4 minggu. C. racemosa tanpa disimpan beku digunakan sebagai pembanding. Filtrat C. racemosa dipisahkan langsung dilapangan menggunakan slow juicer. Kedua bahan tersebut disimpan dalam coolbox berisi es curai dan dianalisis segera setelah sampai di lokasi.

Parameter yang diukur yaitu rendemen $C$. racemosa tiris, drip, dan filtrat. Disamping itu, sampel juga diuji parameter kimianya yaitu kadar air (BSN, 2015), kadar abu (BSN, 2010a), kadar lemak dengan metode Soxhlet (BSN, 2010b), kadar protein dengan metode Kjeldahl menggunakan Foss Kjeltech 8400 (BSN, 2010c), dan kadar garam yang dihitung sebagai $\mathrm{NaCl}$ (BSN, 1991). Parameter fisik yang diamati meliputi uji viskositas menggunakan viskometer Brookfield LVDV-II (Brookfield, USA) dan uji warna menggunakan Hunterlab ColorFlex (Hunterlab Reston, USA) dengan panjang gelombang $400-700 \mathrm{~nm}$. Hasil pengujian warna menghasilkan tiga nilai yaitu $L^{*}$ (kecerahan dengan rentang nilai 1-100), $a^{*}$ (kehijauankemerahan), dan $\mathrm{b}^{*}$ (kebiruan-kekuningan).

\section{Analisis statistik}

Penelitian menggunakan Rancangan Acak Lengkap dengan 3 kali ulangan. Data dianalisis dengan Anova dan jika menunjukkan adanya pengaruh nyata, maka pengujian dilanjutkan dengan uji Tukey untuk melihat beda nyata $(p<0,05)$ antar waktu 
pengamatan. Analisis statistik dilakukan dengan SPSS Version 18 (IBM, USA).

\section{HASIL DAN PEMBAHASAN}

\section{C. racemosa dan Drip Selama Penyimpanan Beku}

\section{Rendemen C. racemosa tiris dan drip}

Perubahan C. racemosa selama penyimpanan beku dapat dilihat dari perubahan sifat/parameter fisika dan kimiawinya setelah thawing. Gambar 1 memperlihatkan rendemen $C$. racemosa tiris dan drip setelah penyimpanan beku selama 4 minggu. Rendemen $C$. racemosa tiris selama penyimpanan beku berkisar $15,20-22,12 \%(b / b)$, tidak berbeda nyata antar waktu penyimpanan $(p>0,05)$. Nilai perolehan C. racemosa tiris tersebut jauh lebih kecil dibanding sampel tanpa disimpan beku. Hal itu menunjukkan bahwa sekitar $80 \%$ cairan keluar dari dalam talusnya setelah sampel beku di-thawing. Berdasarkan Gambar 1 , rendemen $C$. racemosa tiris yang diperoleh menurun seiring dengan meningkatnya jumlah drip yang keluar dari talus. Sama halnya dengan produk buah dan sayuran yang disimpan beku, akan terjadi perubahan daya ikat air yang menyebabkan terbentuknya drip ketika di-thawing (van der Sman, 2020).

Drip yang terbentuk setelah thawing $C$. racemosa beku berkisar $77,88-84,81 \%$ (b/b). Pada C. racemosa tanpa disimpan beku, tidak ada cairan yang keluar setelah penirisan selama 10 menit. Jumlah drip terbentuk setelah thawing tidak berbeda nyata $(p>0,05)$ antar waktu penyimpanan walaupun terlihat adanya sedikit peningkatan jumlah drip seiring bertambahnya waktu penyimpanan. Hasil penelitian Sihono, Tarman, Madduppa, dan Januar (2018) menunjukkan bahwa drip yang keluar dari rumput laut membawa cairan dari dalam talus berupa mineral, garam, dan senyawa lain. Pada proses pembekuan buah yang memiliki kadar air tinggi, akan terbentuk kristal es yang dimulai pada ekstraseluler sel dan berlanjut ke intraseluler sel. Kristal es yang semakin membesar dapat menyebabkan kerusakan pada dinding sel. Dengan demikian, pada saat dilakukan thawing, cairan dalam sel akan keluar (Nesvadba, 2008; Zhou, 2016).

\section{Karakteristik kimia C. racemosa tiris dan drip}

\section{Kadar air}

Penurunan kualitas $C$. racemosa selama penyimpanan dapat juga diamati dari karakteristik kimianya, berupa kadar air, abu, lemak, protein, dan kadar garam (Tabel 1). Kadar air produk pangan sangat penting diketahui agar penanganan dapat dilakukan secara tepat untuk mempertahankan mutu dan daya awet bahan pangan tersebut. Penyimpanan beku sangat mempengaruhi kadar air dari produk sayur dan buah yang telah disimpan beku (Bonat Celli, Ghanem, \& Su-Ling Brooks, 2016).

Kadar air $C$. racemosa tiris setelah penyimpanan beku berkisar $87,18-90,17 \%(b / b)$, lebih rendah $(p<0,05)$ dibanding sampel tanpa disimpan beku yang sebesar 96,03 $\pm 0,79 \%$ (b/b). Hal ini mengindikasikan

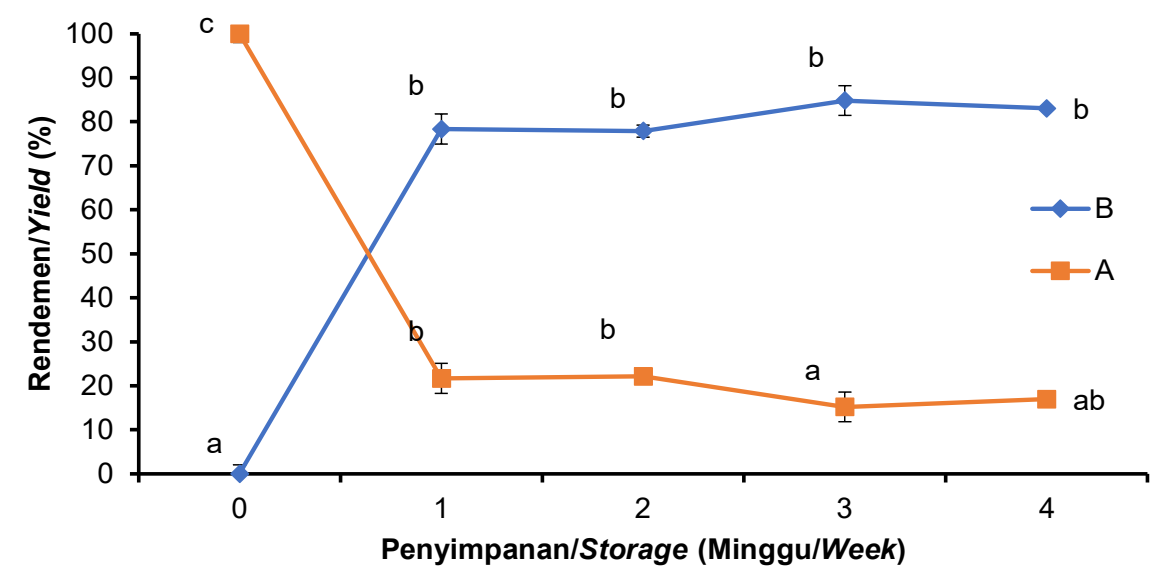

Keterangan/Notes:

- A: C. racemosa tiris /Drained $\underline{C}$. racemosa

- B: Drip yang keluar dari talus IDrip that comes out of the thallus

- Nilai pada garis yang sama dengan anotasi berbeda menunjukkan beda nyata $(p<0,05)$ antar lama penyimpanan/ Values in the same line with different anotation indicate significantly different $(p<0.05)$ between storage period

Gambar 1. Rendemen $C$. racemosa tiris dan drip selama penyimpanan

Figure 1. The yield of drained seaweed and drip during storage 
Tabel 1. Karakteristik kimia C. racemosa tiris dan drip

Table 1. Chemical characteristic of drained $\underline{\text { C. racemosa and drip }}$

\begin{tabular}{|c|c|c|c|c|c|c|}
\hline \multirow{2}{*}{$\begin{array}{l}\text { Sampel/ } \\
\text { Sample }\end{array}$} & \multirow{2}{*}{$\begin{array}{l}\text { Parameterl } \\
\text { Parameters }\end{array}$} & \multicolumn{5}{|c|}{ Waktu penyimpanan (minggu)/Storage time (week) } \\
\hline & & $0^{*}$ & 1 & 2 & 3 & 4 \\
\hline \multirow{5}{*}{$\begin{array}{c}\text { C. racemosa } \\
\text { tiris/ } \\
\text { Drained } \underline{\text { C. }} \\
\underline{\text { racemosa }}\end{array}$} & $\begin{array}{l}\text { Kadar air/ } \\
\text { Moisture content (\%) }\end{array}$ & $96.03 \pm 0.79^{b}$ & $90.17 \pm 1.01^{a}$ & $89.13 \pm 0.60^{a}$ & $87.18 \pm 3.65^{\mathrm{a}}$ & $89.78 \pm 0.14^{2}$ \\
\hline & $\begin{array}{l}\text { Kadar abu/ } \\
\text { Ash content (\%) }\end{array}$ & $2.98 \pm 0.09^{\mathrm{a}}$ & $3.20 \pm 0.10^{\mathrm{ab}}$ & $3.23 \pm 0.10^{b}$ & $3.21 \pm 0.12^{b}$ & $3.15 \pm 0.04^{\mathrm{ab}}$ \\
\hline & $\begin{array}{l}\text { Kadar lemak/ } \\
\text { Fat content }(\%)\end{array}$ & $2^{a}$ & $0.45 \pm 0.03^{b}$ & $0.13^{\mathrm{C}}$ & 0.6 & $.02^{b}$ \\
\hline & $\begin{array}{l}\text { Kadar protein/ } \\
\text { Protein content }(\%)\end{array}$ & $0.35 \pm 0.11^{\mathrm{a}}$ & $1.97 \pm 0.12^{b}$ & $2.57 \pm 0.17^{\mathrm{bc}}$ & $2.06 \pm 0.18^{b}$ & $1.90 \pm 0.09^{b}$ \\
\hline & $\begin{array}{l}\text { Kadar garam/ } \\
\text { Salt content }(\%)\end{array}$ & $1.57 \pm 0.43^{\mathrm{a}}$ & $1.41 \pm 0.04^{\mathrm{a}}$ & $1.31 \pm 0.05^{\mathrm{a}}$ & $1.29 \pm 0.19^{\mathrm{a}}$ & $1.08 \pm 0.14^{\mathrm{a}}$ \\
\hline \multirow{5}{*}{ Drip } & $\begin{array}{l}\text { Kadar air/ } \\
\text { Moisture content (\%) }\end{array}$ & - & $97.32 \pm 0.01^{\mathrm{a}}$ & $97.24 \pm 0.03^{\mathrm{a}}$ & $97.99 \pm 0.28^{b}$ & $97.39 \pm 0.06^{a}$ \\
\hline & $\begin{array}{l}\text { Kadar abu/ } \\
\text { Ash content (\%) }\end{array}$ & - & $2.29 \pm 0.06^{a}$ & $2.32 \pm 0.07^{\mathrm{a}}$ & $2.18 \pm 0.04^{a}$ & $2.29 \pm 0.06^{a}$ \\
\hline & $\begin{array}{l}\text { Kadar lemak/ } \\
\text { Fat content (\%) }\end{array}$ & - & $0.00 \pm 0.00^{\mathrm{a}}$ & $0.00 \pm 0.00^{\mathrm{a}}$ & $0.00 \pm 0.00^{\mathrm{a}}$ & $0.00 \pm 0.00^{\mathrm{a}}$ \\
\hline & $\begin{array}{l}\text { Kadar protein/ } \\
\text { Protein content (\%) }\end{array}$ & - & $0.13 \pm 0.01^{\mathrm{b}}$ & $0.00 \pm 0.00^{\mathrm{a}}$ & $0.00 \pm 0.00^{\mathrm{a}}$ & $0.00 \pm 0.00^{\mathrm{a}}$ \\
\hline & $\begin{array}{l}\text { Kadar garam/ } \\
\text { Salt content (\%) }\end{array}$ & - & $2.07 \pm 0.13^{\mathrm{c}}$ & $1.74 \pm 0.16^{b c}$ & $1.60 \pm 0.24^{b}$ & $1.05 \pm 0.09^{\mathrm{a}}$ \\
\hline
\end{tabular}

adanya air yang keluar setelah sampel di-thawing setelah penyimpanan beku. Pada drip, kadar air berkisar 97,24-97,99\%. Berdasarkan uji statistik, tidak ditemukan adanya perbedaan kadar air drip selama periode penyimpanan 4 minggu $(p>0,05)$. Setelah penyimpanan beku, air dalam rumput laut mudah keluar dari dalam talusnya. Hal yang sama juga ditemukan pada produk buah dan sayuran. Pada proses pembekuan, cairan dalam sel akan membentuk kristal es dan akan keluar dari dalam sel saat produk di-thawing. Kerusakan sel akibat pembekuan ini bersifat ireversibel dan dapat mengubah tekstur produk buah dan sayur sehingga menurunkan kualitas produk (Charoenrein, 2018; Sun \& Li, 2003).

\section{Kadar abu}

Abu merupakan zat anorganik sisa hasil pembakaran suatu biomassa. Kadar abu pada rumput laut terdiri atas makro mineral dan trace element (Mayer, Rodríguez, Berlinck, \& Fusetani, 2011). Makro mineral tertinggi rumput laut adalah $\mathrm{Na}$, diikuti oleh $\mathrm{K}, \mathrm{Ca}$, dan $\mathrm{Mg}$, sementara mikro mineralnya terdiri atas $\mathrm{Fe}, \mathrm{Zn}$, dan $\mathrm{Cu}$ (Kumar et al., 2011). Menurut Ratana-arporn dan Chirapart (2006), tinggi rendahnya kadar abu dapat dihubungkan dengan kadar unsur mineral yang terkandung dalam bahan, yaitu semakin tinggi kandungan mineralnya, maka semakin tinggi kadar abunya. Kandungan mineral rumput laut dipengaruhi oleh spesies, faktor fisiologis, kondisi geografis (Rupérez, 2002), habitat tumbuh, dan cara pengeringan rumput lautnya (Tapotubun, 2018). Kadar abu C. racemosa tanpa disimpan beku yang digunakan pada penelitian ini $2,98 \pm 0,09 \%$, lebih rendah dibanding $C$. rasemosa asal Jepara, yaitu $5,22 \%$ (Sedjati, 1999).

Kadar abu C. racemosa tiris setelah penyimpanan beku berkisar 3,15-3,23\%, tidak berbeda nyata antar lama penyimpanan $(p>0,05)$. Hal ini juga ditemukan pada produk sayur, ketika dibekukan dalam jangka waktu 10 bulan, kandungan abu/mineral ( $\mathrm{Ca}, \mathrm{K}, \mathrm{Mg}$, dan P) sayur tersebut tidak berubah (Martý'nezRomero, Castillo, \& Valero, 2004). Namun, kadar abu C. rasemosa tiris setelah penyimpanan beku berbeda nyata $(p<0,05)$ dengan yang tanpa penyimpanan beku. Hal serupa juga ditemukan pada kadar abu drip $C$. racemosa yang menunjukkan tidak adanya perbedaan nyata antar waktu penyimpanan $(p>0,05)$ dengan kadar abu 2,18-2,32\%.

\section{Kadar lemak}

Rumput laut umumnya memiliki kandungan lemak yang rendah (Ma'ruf et al., 2013). Kadar lemak $C$. racemosa yang mengalami penyimpanan beku sangat rendah, yaitu berkisar $0,41-0,63 \%$. Terdapat perbedaan nyata $(p<0,05)$ kadar lemak antara sampel tanpa disimpan beku dengan sampel yang mengalami penyimpanan beku. Hal ini diduga karena perbedaan kadar air, yaitu C. racemosa tanpa disimpan beku 
memiliki kadar air yang lebih tinggi dibandingkan dengan C. racemosa tiris. Drip yang keluar setelah proses thawing tidak mengandung lemak. Hal ini terkait dengan sifat lemak yang tidak larut dalam senyawa polar, sehingga tidak ikut terlarut dalam drip.

\section{Kadar protein}

Kandungan protein rumput laut dipengaruhi oleh banyak faktor, diantaranya perbedaan spesies, musim, dan letak geografis (Ratana-arporn \& Chirapart, 2006). C. racemosa yang disimpan beku memiliki kadar protein yang cukup rendah, yaitu 1,90-2,57 \%. Kadar protein $C$. racemosa tanpa disimpan beku lebih tinggi $(p<0,05)$ dibandingkan sampel yang disimpan beku. Hal ini diduga karena kadar air C. racemosa tanpa disimpan beku lebih tinggi dibandingkan dengan sampel yang disimpan beku. Kadar protein drip C. racemosa pada penyimpanan minggu pertama sekitar $0,13 \%$, namun tidak terdeteksi pada penyimpanan minggu selanjutnya. Hal ini diduga karena terjadinya denaturasi protein setelah dilakukan thawing pada C. racemosa beku. Protein yang terdenaturasi berkurang kelarutannya sehingga saat cairan keluar dari talus, protein tidak ikut keluar bersama drip (van der Sman, 2020).

\section{Kadar garam}

Sekitar $80 \%$ mineral pada $C$. racemosa tersusun atas $\mathrm{NaCl}$, sisanya terdiri dari mineral-mineral lainnya (Sedjati, 1999). Sivakumar dan Arunkumar (2009) juga melaporkan bahwa rumput laut hijau mengandung mineral Na yang tinggi. Hampir semua jenis rumput laut mengabsorbsi mineral yang ada di perairan melalui seluruh permukaan talusnya. Mineral tersebut terserap melalui stomata dengan proses biokimia kompleks dan diubah menjadi suatu deposit yang tersimpan dalam dinding sel (Sedjati, 1999).

Kadar garam C. racemosa setelah tiris $1,08-$ $1,41 \%$. Kadar garam sampel tiris mengalami peningkatan pada minggu pertama sampai minggu ke- 4 , tapi tidak berbeda nyata $(p>0,05)$. Kadar garam C. racemosa setelah penyimpanan beku lebih rendah dibanding tanpa disimpan beku. Hal ini menunjukkan adanya garam terlarut di dalam drip yang keluar dari talus $C$. racemosa. Kadar garam drip yang keluar dari talus $C$. racemosa setelah thawing 1,05-2,07\%. Kadar garam drip setelah penyimpanan beku dari minggu pertama hingga minggu keempat mengalami penurunan yang nyata $(p<0,05)$.

\section{Karakteristik fisik drip C. racemosa}

Sifat fisik drip dari C. racemosa setelah penyimpanan beku yang meliputi warna dan viskositas dapat dilihat pada Tabel 2. Pada penyimpanan minggu pertama, drip menunjukkan warna keruh kehijauan $\left(L^{*}\right.$ $\left.=18,04 ; a^{*}=-2,66 ; b^{*}=11,69\right)$. Semakin lama waktu penyimpanan menyebabkan peningkatan nilai $L^{*}$ dan $b^{*}$, serta penurunan nilai $a^{*}$. Perbedaan nyata $(p<0,05)$ terlihat pada $L^{*}$ dan $b^{*}$ drip penyimpanan minggu ke1 dan ke-4, sementara nilai $a^{*}$ tidak berbeda nyata $(p>0,05)$. $L^{*}$ drip selama penyimpanan menunjukkan nilai yang relatif rendah dengan rentang antara 4,78 7,04 , mengindikasikan warna yang gelap. Pada $a^{*}$ drip minggu ke-1 hingga ke-4 memberikan hasil yang negatif (-0,40 sampai -0.96), mengindikasikan warna kehijauan. Semakin negatif nilai $a^{*}$, warna kehijauan akan semakin tua. Warna kehijauan ini berasal dari keberadaan pigmen klorofil pada C. racemosa. Paul, Neveux, Magnusson, \& de Nys (2014) melaporkan bahwa $C$. racemosa mengandung total klorofil sebesar $9 \mathrm{mg} / \mathrm{g}$, terdiri dari klorofil a dan b berturut-turut sebesar 5,77 dan $3,22 \mathrm{mg} / \mathrm{g}$. -Nilai b* drip menunjukkan hasil yang positif $(0,70-1,90)$, yang mengindikasikan warna kekuningan. Hingga saat ini tidak ada penelitian yang melaporkan analisis warna untuk drip C. racemosa. Warna drip dapat dibandingkan dengan warna jus anggur hijau karena

Tabel 2. Karakteristik fisik drip yang keluar dari talus

Table 2. Physical characterstics of seaweed drip that comes out of the seaweed thallus

\begin{tabular}{ccccc}
\hline \multirow{2}{*}{$\begin{array}{c}\text { Parameterl } \\
\text { Parameters }\end{array}$} & \multicolumn{4}{c}{ Waktu penyimpanan (minggu)/Storage time (week) } \\
\cline { 2 - 5 } & $\mathbf{1}$ & $\mathbf{2}$ & $\mathbf{3}$ & $\mathbf{4}$ \\
\hline $\mathrm{L}^{*}$ & $4.78 \pm 0.05^{\mathrm{a}}$ & $5.28 \pm 0.62^{\mathrm{ab}}$ & $6.29 \pm 1.20^{\mathrm{ab}}$ & $7.04 \pm 1.08^{\mathrm{b}}$ \\
$\mathrm{a}^{*}$ & $-0.40 \pm 0.11^{\mathrm{b}}$ & $-0.67 \pm 0.02^{\mathrm{ab}}$ & $-0.67 \pm 0.32^{\mathrm{ab}}$ & $-0.96 \pm 0.17^{\mathrm{a}}$ \\
$\mathrm{b}^{*}$ & $0.70 \pm 0.08^{\mathrm{a}}$ & $1.28 \pm 0.18^{\mathrm{a}}$ & $1.53 \pm 0.74^{\mathrm{a}}$ & $1.90 \pm 0.52^{\mathrm{a}}$ \\
Viskositas/Viscosity (cP) & $1.34 \pm 0.01^{\mathrm{a}}$ & $1.35 \pm 0.01^{\mathrm{a}}$ & $1.52 \pm 0.38^{\mathrm{a}}$ & $1.71 \pm 0.13^{\mathrm{a}}$ \\
\hline
\end{tabular}

Keterangan/Notes:

$L^{*}$ : Kecerahan/Lightness

$a^{*}$ : Kehijauan-kemerahan/Greenness-redness

$b^{*}$ : Kebiruan-kekuningan/Blueness-yellowness 
memiliki warna yang serupa, yaitu kehijauan. Anggur hijau memiliki nilai $L^{*}=94,41$; $a^{*}=-2,33$; dan $b^{*}=$ 7,99, lebih tinggi dibandingkan drip C. racemosa (Segura, Salvadori, \& Goñi, 2017), tetapi pengaruh suhu penyimpanan terhadap warna belum pernah dilaporkan.

Hasil analisis viskositas menunjukkan viskositas drip yang keluar dari talus setelah penyimpanan beku berkisar 1,34-1,71 cP. Hal ini menunjukkan terdapat peningkatan viskositas seiring dengan waktu penyimpanan beku. Namun, hasil analisis statistik menunjukkan tidak terdapat perbedaan $(p>0,05)$ viskositas drip selama periode penyimpanan. Nilai viskositas sangat bergantung pada temperatur dan kandungan padatan terlarut (Juszczak \& Fortuna, 2003). Berdasarkan hasil analisis, drip hanya mengandung garam $(1,05-2,07 \%)$ dan protein yang rendah $(0-0,13 \%)$.

\section{Filtrat C. racemosa Selama Penyimpanan Beku}

Penggunaan filtrat Caulerpa pada produk pangan diantaranya untuk meningkatkan cita rasa khas pada produk saus (Murdinah et al., 2020). Selain itu, filtrat Caulerpa dapat meningkatkan nutrisi pada mi basah, seperti kandungan antioksidan dan beta karoten (Agusman et al., 2020). Filtrat Caulerpa juga dapat digunakan pada pembuatan bulir (boba) yang kaya akan nutrisi (Nurhayati, Basmal, Sinurat, \& Fransiska, 2021). Hasil pengamatan secara visual menunjukkan bahwa filtrat yang diperoleh dari $C$. racemosa tanpa disimpan beku dan $C$ racemosa yang telah disimpan beku memiliki homogenitas yang berbeda saat disimpan kembali pada kondisi beku. Filtrat yang diperoleh dari C. racemosa tanpa disimpan beku memiliki stabilitas yang lebih baik (lebih homogen) dibandingkan filtrat yang diperoleh dari C. racemosa yang telah dibekukan dan lebih cepat terbentuk 2
Iapisan terpisah. Dua lapisan tersebut terbentuk karena adanya pengendapan dari komponen yang tidak larut. Ukuran partikel yang tidak seragam dari komponen tidak larut menyebabkan filtrat tidak terdispersi secara merata. Selain itu, bahan tidak larut umumnya memiliki berat molekul (BM) yang tinggi sehingga pengendapan menjadi lebih mudah terjadi.

\section{Rendemen dan karakteristik kimia filtrat $C$. racemosa}

Filtrat diperoleh dari hasil juicer C. racemosa yang telah ditiriskan. Rendemen dan kandungan kimia filtrat C. racemosa yang diperoleh dapat dilihat pada Tabel 3 . Rendemen filtrat $C$. racemosa berkisar 4,76$10,12 \%$, sedangkan filtrat yang diperoleh dari $C$. racemosa yang tidak disimpan beku sebesar $91,21 \%$. Filtrat yang diperoleh dari $C$. rasemosa yang telah dibekukan memiliki rendemen 9-21 kali lebih rendah dibandingkan filtrat yang diperoleh dari C. racemosa yang tidak disimpan beku. Hasil analisis statistik menunjukkan perolehan filtrat Caulerpa dari sampel yang disimpan beku berbeda nyata $(p<0,05)$ dengan filtrat yang diperoleh dari sampel yang tidak disimpan beku. Perolehan filtrat $C$. racemosa menurun pada penyimpanan minggu ke- 2 hingga ke- 4 , namun tidak terlihat perbedaan yang signifikan $(p>0,05)$. Penurunan rendemen filtrat tersebut disebabkan karena sebagian besar drip keluar dari talus maupun ramulinya, sehingga berat $C$. racemosa yang telah dibekukan jauh menurun dibandingkan $C$. racemosa yang tidak dibekukan.

Kadar air filtrat yang diperoleh dari C. racemosa yang telah mengalami penyimpanan beku berkisar 93,71-94,74\%. Hasil analisis statistik menunjukkan kadar air filtrat $C$. racemosa yang tidak disimpan beku secara signifikan lebih tinggi $(p<0,05)$ dari $C$. racemosa yang disimpan beku. Kadar abu filtrat $C$. racemosa beku yang berkisar 3,64-4,52\%

Tabel 3. Rendemen dan karakteristik kimia filtrat $C$. racemosa

Table 3. Yield and chemical characteristic of $\underline{\text { C. }}$ racemosa filtrate

\begin{tabular}{|c|c|c|c|c|c|}
\hline \multirow{2}{*}{ Parameter/Parameters } & \multicolumn{5}{|c|}{ Waktu Penyimpanan (Minggu)/Storage Time (Week) } \\
\hline & $0^{*}$ & 1 & 2 & 3 & 4 \\
\hline Rendemen filtrat/Yield of filtrate (\%) & $91.21 \pm 1.92^{\mathrm{C}}$ & $10.12 \pm 0.21^{b}$ & $8.09 \pm 1.21^{a}$ & $4.76 \pm 0.37^{a}$ & $6.52 \pm 1.56^{a}$ \\
\hline Kadar air/Moisture content (\%) & $97.77 \pm 0.22^{d}$ & $94.74 \pm 0.06^{\mathrm{bc}}$ & $94.24 \pm 0.16^{\mathrm{ab}}$ & $95.48 \pm 0.05^{\mathrm{c}}$ & $93.71 \pm 0.71^{\mathrm{a}}$ \\
\hline Kadar abu/Ash content (\%) & $0.62 \pm 0.03^{\mathrm{a}}$ & $3.72 \pm 0.01^{b}$ & $3.64 \pm 0.08^{b}$ & $4.52 \pm 0.05^{\mathrm{c}}$ & $4.30 \pm 0.34^{c}$ \\
\hline Kadar lemak/Fat content (\%) & $0.15 \pm 0.04^{\mathrm{ab}}$ & $0.17 \pm 0.02^{b}$ & $0.57 \pm 0.03^{d}$ & $0.37 \pm 0.02^{c}$ & $0.09 \pm 0.00^{\mathrm{a}}$ \\
\hline Kadar protein/Protein content (\%) & $0.15 \pm 0.02^{\mathrm{a}}$ & $0.48 \pm 0.07^{\mathrm{a}}$ & $0.69 \pm 0.08^{a}$ & $0.28 \pm 0.01^{a}$ & $0.64 \pm 0.05^{\mathrm{a}}$ \\
\hline Kadar garam/Salt content (\%) & $0.09 \pm 0.04^{a}$ & $1.65 \pm 0.28^{b}$ & $1.69 \pm 0.08^{\mathrm{b}}$ & $1.80 \pm 0.16^{b}$ & $1.82 \pm 0.34^{b}$ \\
\hline
\end{tabular}

Keterangan/Note: *Filtrat dari C. racemosa yang tidak disimpan beku/ Filtrate from unfrozen $\underline{\text { C. }} \underline{\text { racemosa }}$ 
menunjukkan nilai yang lebih tinggi $(p<0,05)$ dibandingkan filtrat $C$. racemosa yang tidak disimpan beku. Pada $C$. racemosa yang disimpan beku, sekitar $80 \%$ drip keluar dari talus C. racemosa, sehingga berat awal filtrat menjadi semakin berkurang. Dengan demikian, kadar abu filtrat $C$. racemosa setelah penyimpanan beku lebih tinggi dibanding C. racemosa yang tidak disimpan beku.

Kadar lemak filtrat $C$. racemosa cukup rendah, yaitu $0,09-0,57 \%$, dan berbeda nyata $(p<0,05)$ pada setiap perlakuan lama penyimpanan. Penurunan kadar lemak diduga karena terjadinya reaksi oksidasi lemak pada saat thawing. Proses thawing menyebabkan sampel terpapar udara bebas dan terkena cahaya langsung sehingga mempercepat terjadinya reaksi oksidasi lemak (Winarno, 1997). Lemak rumput laut umumnya tersusun atas asam lemak tak jenuh berikatan rangkap ganda (polyunsaturated fatty acids, PUFA), yang rentan terhadap reaksi oksidasi (Ortiz et al., 2006; Winarsi, 2007).

Kadar protein filtrat $C$. racemosa berkisar 0,28 $0,69 \%$ dan tidak terdapat perbedaan nyata $(p>0,05)$ antar lama penyimpanan beku. Kadar garam filtrat C. racemosa yang disimpan beku berkisar 1,65$1,82 \%$, tidak berbeda nyata selama waktu penyimpanan $(p>0,05)$, namun lebih tinggi dari $C$. racemosa yang tidak disimpan beku $(p<0,05)$. Filtrat pada $C$. racemosa tanpa disimpan beku masih mengandung drip, sementara pada sampel yang disimpan beku telah kehilangan sebagian besar drip, sehingga menyebabkan berkurangnya total massa sampel.

\section{Karakteristik fisik filtrat $C$. racemosa}

Karakteristik fisik filtrat $C$. racemosa berupa warna $\left(L^{*}, a^{*}, b^{*}\right)$ dan viskositas dapat dilihat pada Tabel 4. Nilai $L^{*}$ filtrat $C$. racemosa semakin menurun mulai dari penyimpanan minggu ke-1 hingga ke-4. $L^{*}$ filtrat yang diperoleh dari $C$. racemosa yang disimpan beku selama satu minggu berbeda nyata $(p<0,05)$ dengan yang disimpan beku 2-3 minggu. Produk lain yang dapat dibandingkan dengan filtrat $C$. racemosa yaitu jus bayam yang memiliki warna yang serupa. Nilai $L^{*}$ filtrat C. racemosa $(18,04-30,69)$ lebih tinggi dibanding jus bayam dengan rentang nilai $L^{*} 11,93-23,48$ (Khandpur \& Gogate, 2015). Sementara itu, nilai a* tertinggi dihasilkan dari $C$. racemosa yang disimpan beku selama 1 minggu, sedangkan nilai terendah dari yang disimpan beku selama 3 minggu $(p<0,05)$. Secara umum filtrat dengan nilai $a^{*}$ negatif mengindikasikan sampel berwarna hijau. Warna kehijauan filtrat $C$. racemosa $(-4,13$ sampai -0.98$)$ hampir sama dengan jus bayam, yaitu sebesar $-5,25$ sampai $-1,08$ (Khandpur \& Gogate, 2015). Nilai b* semakin menurun seiring lamanya waktu penyimpanan $(p<0,05)$. Nilai $b^{*}$ ini $(11,69-24,50)$ juga tidak jauh berbeda dengan jus bayam, yaitu $10,08-$ 30,26 . Pada sawi hijau, penyimpanan pada suhu dingin menyebabkan peningkatan nilai $L^{*}, a^{*}$, dan $b^{*}$ (Awanis \& Darmawati, 2020). Jika diolah menjadi jus, maka warna jus kemungkinan besar akan memiliki pola peningkatan warna yang sama dengan bahan bakunya. Berbeda dengan nilai $a^{*}$ pada sawi hijau, $a^{*}$ drip maupun filtrat $C$. rasemosa mengalami penurunan nilai. Hal ini disebabkan karena sawi hijau disimpan pada suhu dingin $\left(13^{\circ} \mathrm{C}\right)$ sehingga masih memungkinkan terjadinya degradasi pigmen klorofil. Roiyana, Prihastanti, \& Kasiyati (2011) melaporkan bahwa penyimpanan sayuran pada suhu lebih rendah dapat menurunkan aktivitas enzim klorofilase sehingga menghambat pendegradasian senyawa klorofil. Filtrat yang dihasilkan dari C. racemosa yang disimpan dalam kondisi beku cenderung tetap memiliki warna hijau dan bisa digunakan sebagai pewarna alami untuk makanan.

Hasil uji viskositas filtrat $C$. racemosa dapat dilihat pada Tabel 4. Secara umum, viskositas filtrat memiliki

Tabel 4. Karakteristik fisik filtrat $C$. racemosa

Table 4. Chemical characteristic of $\underline{\text { C. }}$ racemosa filtrate

\begin{tabular}{ccccc}
\hline \multirow{2}{*}{ Parameter/Parameters } & \multicolumn{4}{c}{ Waktu Penyimpanan (Minggu)/Storage Time (Week) } \\
\cline { 2 - 5 } & $\mathbf{1}$ & $\mathbf{2}$ & $\mathbf{3}$ & $\mathbf{4}$ \\
\hline $\mathrm{L}^{*}$ & $18.04 \pm 1.37^{\mathrm{a}}$ & $22.81 \pm 0.03^{\mathrm{b}}$ & $30.69 \pm 2.37^{\mathrm{b}}$ & $27.52 \pm 2.98^{\mathrm{b}}$ \\
$\mathrm{a}^{*}$ & $-2.66 \pm 0.05^{\mathrm{a}}$ & $-4.13 \pm 0.05^{\mathrm{a}}$ & $-0.98 \pm 1.32^{\mathrm{b}}$ & $-2.62 \pm 0.78^{\mathrm{b}}$ \\
$\mathrm{b}^{*}$ & $11.69 \pm 0.72^{\mathrm{a}}$ & $23.12 \pm 0.05^{\mathrm{b}}$ & $24.39 \pm 0.16^{\mathrm{ab}}$ & $24.50 \pm 0.82^{\mathrm{ab}}$ \\
Viskositas/Viscosity (CP) & $225.30 \pm 13.59^{\mathrm{a}}$ & $94.09 \pm 6.51^{\mathrm{a}}$ & $81.20 \pm 53.10^{\mathrm{a}}$ & $235.85 \pm 53.10^{\mathrm{a}}$ \\
\hline
\end{tabular}

Keterangan/Notes:

$\mathrm{L}^{*}$ : Kecerahan/Lightnest

$\mathrm{a}^{*}$ : Kehijauan-kemerahan/Greenness-Redness

$b^{*}$ : Kebiruan-kekuningan/Blueness-yellowness 
nilai yang fluktuatif selama masa penyimpanan. Hal ini diduga karena adanya partikel padatan tak larut yang tidak tersuspensi dalam cairan filtrat sehingga viskositas menjadi tidak stabil. Hal ini berbeda dengan yang dilaporkan Lutpiah (2005), yaitu viskositas jus belimbing yang disimpan di lemari pendingin semakin meningkat seiring waktu penyimpanan, disebabkan karena adanya pengaruh suhu dan mikroorganisme.

\section{KESIMPULAN}

Penyimpanan beku C. racemosa menghasilkan drip akibat adanya thawing sehingga berat rumput laut menjadi berkurang. $C$. racemosa setelah penyimpanan beku memiliki kadar air dan kadar garam yang lebih rendah dibandingkan $C$. racemosa tanpa disimpan beku, namun memiliki kadar abu, protein, dan lemak yang lebih tinggi. Drip hasil thawing C. racemosa yang telah disimpan beku mengandung kadar abu, garam, dan sedikit protein pada penyimpanan minggu pertama, namun tidak terdeteksi adanya lemak. Filtrat C. racemosa yang diperoleh dari hasil juicer mengandung kadar abu, lemak, protein, dan garam lebih tinggi dibandingkan filtrat tanpa disimpan beku.

\section{DAFTAR PUSTAKA}

Agusman, Murdinah, \& Wahyuni, T. (2020). The nutritional quality and preference of wheat noodles incorporated with Caulerpa sp. seaweed. International Food Research Journal, 27(3), 445-453.

Anwar, L. O., Bubun, R. L., \& Rosmawati. (2016). Manfaat anggur laut (Caulerpa racemosa) dan penanganannya dengan melibatkan masyarakat pantai di Desa Rumba-rumba. Senaspro 2016, 110116.

Awanis, \& Darmawati, E. (2020). Pengaruh sistem pendinginan pada dua jenis suhu penyimpanan terhadap kesegaran sawi hijau (Brassica juncea). Jurnal Informasi Teknologi Pertanian (JITP), 1 (1), 1 18

Badan Standardisasi Nasional (BSN). (1991). SNI $01-$ 2359-1991 Produk perikanan, penentuan kadar garam (Badan Standardisasi Nasional, Ed.) . Jakarta: Badan Standardisasi Nasional.

Badan Standardisasi Nasional (BSN) (2010a). SNI 2354.1-2010 Cara uji kimia - Bagian 1: Penentuan kadar abu dan abu tak larut asam pada produk perikanan (Badan Standardisasi Nasional, Ed.) Jakarta: Badan Standardisasi Nasional.

Badan Standardisasi Nasional (BSN). (2010b). SNI 2354.3-2010 Cara uji kimia - Bagian 3: Penentuan kadar lemak total pada produk perikanan (Badan Standardisasi Nasional, Ed.). Jakarta: Badan Standardisasi Nasional.

Badan Standardisasi Nasional (BSN). (2010c). SNI 2354.4-2010 Cara uji kimia - Bagian 4: Penentuan kadar protein dengan metode total nitrogen pada produk perikanan (Badan Standardisasi Nasional, Ed.). Jakarta: Badan Standardisasi Nasional.

Badan Standardisasi Nasional (BSN). (2015). SNI 2354.2-2015 Cara uji kimia- Bagian 2: Penentuan kadar air pada produk perikanan (Badan Standardisasi Nasional, Ed.). Jakarta: Badan Standardisasi Nasional.

Bonat Celli, G., Ghanem, A., \& Su-Ling Brooks, M. (2016). Influence of freezing process and frozen storage on the quality of fruits and fruit products. Food Reviews International, 32(3), 280-304. doi: 0.1080/ 87559129.2015 .1075212

Charoenrein, S. (2018). 7 - Microstructural changes and their relationship with quality and stability of frozen foods. In S. B. T.-F. M. and I. R. with Q. and S. Devahastin (Ed.), Woodhead Publishing Series in Food Science, Technology and Nutrition (pp. 123138). doi: 10.1016/B978-0-08-100764-8.00007-1

Fithriani, D. (2015). Opportunities and challenges for developing Caulerpa racemosa as Functional Food. The 1st International Symposium On Aquatic Product Processing 2013, 1, 85-96.

Hao, H., Fu, M., Yan, R., He, B., Li, M., Liu, Q., ... Huang, R. (2019). Chemical composition and immunostimulatory properties of green alga Caulerpa racemosa var peltata. Food and Agricultural Immunology, 30(1), 937-954. https://doi.org/10.1080/ 09540105.2019 .1646216

Hong, D. D., Hien, H. M., \& Son, P. N. (2007). Seaweeds from Vietnam used for functional food, medicine and biofertilizer. Journal of Applied Phycology, 19(6), 817-826. https://doi.org/10.1007/s10811-007-9228$x$

Juszczak, L., \& Fortuna, T. (2003). Viscosity of concentrated strawberry juice, effect of temperature and soluble solids content. Electronic Journal of Polish Agricultural Universities, Series Food Science and TEchnology, 6(2).

Khandpur, P., \& Gogate, P. R. (2015). Effect of novel ultrasound based processing on the nutrition quality of different fruit and vegetable juices. Ultrasonics Sonochemistry, 27, 125-136. doi: 10.1016/ j.ultsonch.2015.05.008

Kumar, M., Gupta, V., Kumari, P., Reddy, C. R. K., \& Jha, B. (2011). Assessment of nutrient composition and antioxidant potential of Caulerpaceae seaweeds. Journal of Food Composition and Analysis, 24(2), 270-278. doi: 10.1016/j.jfca.2010.07.007

Lutpiah, E. N. (2005). Karakteristik fisik dan nilai pH jus belimbing yang disimpan pada suhu kamar dan lemari pendingin. Skripsi, Program Studi Fisika, Fakultas Matematika dan IImu Pengetahuan Alam, Institut Pertanian Bogor

Ma'ruf, W. F., Ibrahim, R., Dewi, E. N., Susanto, E., \& Amalia, U. (2013). Caulerpa racemosa dan Gracilaria verrucosa sebagai edible food. Jurnal Saintek Perikanan, 9(1), 68-74.

Martýnnez-Romero, D., Castillo, S., \& Valero, D. (2004). Quality control in frozen vegetables. In W.-K. N. Y. H. 
Hui, Isabel Guerrero Legarretta, Miang Hoong Lim, K.D. Murrell (Ed.), Handbook of frozen food processing and packaging (pp. 405-414). doi: 10.1201/9780203912911.ch17

Mayer, A. M. S., Rodríguez, A. D., Berlinck, R. G. S., \& Fusetani, N. (2011). Marine pharmacology in 2007-8: Marine compounds with antibacterial, anticoagulant, antifungal, anti-inflammatory, antimalarial, antiprotozoal, antituberculosis, and antiviral activities; Affecting the immune and nervous system, and other miscellaneous mec. Comparative Biochemistry and Physiology - C Toxicology and Pharmacology, 153(2), 191-222. doi: 10.1016/j.cbpc.2010.08.008

Murdinah, Subaryono, Wahyuni, T., \& Nurhayati. (2020). Formula saus rumput laut hijau Caulerpa dan proses pembuatannya. Usulan Paten. IDP000066670 B.

Nesvadba, P. (2008). Thermal properties and ice crystal development in frozen foods. In Frozen Food Science and Technology. (pp. 1-25). doi: 10.1002/ 9781444302325.ch1

Nurhayati, Basmal, J., Sinurat, E., \& Fransiska, D. (2020). Prospek pengembangan boba sehat dari anggur laut. 112 Inovasi Indonesia Business Innovasion Center, 104.

Ortiz, J., Romero, N., Robert, P., Araya, J., LopezHernández, J., Bozzo, C., ... Rios, A. (2006). Dietary fiber, amino acid, fatty acid and tocopherol contents of the edible seaweeds Ulva lactuca and Durvillaea antarctica. Food Chemistry, 99(1), 98-104. doi: 10.1016/j.foodchem.2005.07.027

Paul, N. A., Neveux, N., Magnusson, M., \& de Nys, R. (2014). Comparative production and nutritional value of "sea grapes" - the tropical green seaweeds Caulerpa lentillifera and C. racemosa. Journal of Applied Phycology, 26(4), 1833-1844. doi: 10.1007/s10811-013-0227-9

Pereira, L. (2011). A review of the nutrient composition of selected edible seaweeds. In Vitor H. Pomin (Ed.), Seaweed. doi: 10.1108/NFS-07-2014-0063

Putri, L. S. O. (2020). Produksi biskuit fungsional dari tepung rumput laut (Caulerpa racemosa) dan tepung pisang (Musa sp.). Retrieved from http:// www.elsevier.com/locate/scp

Ratana-arporn, P., \& Chirapart, A. (2006). Nutritional evaluation of tropical green seaweeds Caulerpa lentillifera and Ulva reticulata. Kasetsart Journal (Natural Science), 40, 75-83.

Roiyana M., Prihastanti E., Kasiyati. 2011. Pengaruh Suhu dan Lama Penyimpanan Daun Stephania hernandifolia Walp. terhadap Kualitas Bahan Baku Cincau dan Penerimaan Konsumen. Buletin Anatomi dan Fisiologi, 19 (2): 10-19

Rupérez, P. (2002). Mineral content of edible marine seaweeds. Food Chemistry, 79(1), 23-26. doi: 10.1016/S0308-8146(02)00171-1

Safaryani, N., Haryanti, S., \& Hastuti, E. D. (2007). Pengaruh suhu dan lama penyimpanan terhadap penurunan kadar vitamin C brokoli (Brassica oleracea L). Buletin Anatomi Fisiologi, XV(2), 39-45. doi: $10.14710 /$ baf.v15i2.2571

Sanjaya, Y. A., Widjanarko, S. B., \& Setijawati, D. (2016). phytochemicals properties and fatty acid profile of green seaweed Caulerpa racemosa from Madura, Indonesia. International Journal of ChemTech Research, 9(05), 425-431.

Sedjati. (1999). Kadar proksimat rumput laut Caulerpa racemosa dan C. serrulata di Perairan Teluk Awur, Jepara. Makalah IImiah, FPIK-UNDIP, Semarang, 20 p.

Segura, L. I., Salvadori, V. O., \& Goñi, S. M. (2017). Characterisation of liquid food colour from digital images. International Journal of Food Properties, 20(1), S467-S477. doi: 10.1080/10942912.2017.1299758

Siah, W. M., Aminah, A., \& Ishak, A. (2014). Optimization of soaking conditions for the production of seaweed (Kappaphycus alverazii) paste using response surface methodology. International Food Research Journal, 21(2), 471-477.

Sihono, S., Tarman, K., Madduppa, H., \& Januar, H. I. (2018). Metabolite profiles and antioxidant activity of Caulerpa racemosa with different handlings. Squalen Bulletin of Marine and Fisheries Postharvest and Biotechnology, 13(3), 93. doi: 10.15578/ squalen.v13i3.355

Sivakumar, S. R., \& Arunkumar, K. (2009). Sodium, potassium and suphate composition in some seaweeds occuring along the Coast of Gulf of Mannar, India. Asian Journal of Plant Sciences, 8(7), 500-504.

Sun, D. W., \& Li, B. (2003). Microstructural change of potato tissues frozen by ultrasound-assisted immersion freezing. Journal of Food Engineering, 57(4), 337-345. doi: 10.1016/S0260-8774(02)00354-0

Tapotubun, A. M. (2018). Komposisi Kimia rumput laut (Caulerpa lentillifera) dari Perairan Kei Maluku dengan metode pengeringan berbeda. Jurnal Pengolahan Hasil Perikanan Indonesia, 21(1), 1323. doi: 10.17844/jphpi.v21i1.21257

van der Sman, R. G. M. (2020). Impact of processing factors on quality of frozen vegetables and fruits. Food Engineering Reviews, 12(4), 399-420. doi: 10.1007/ s12393-020-09216-1

Winarno, F. G. 1997. Kimia Pangan dan Gizi. Gramedia Pustaka Utama. Jakarta.

Winarsi, H. 2007. Antioksidan Alami dan Radikal Bebas. Yogyakarta:"Kanisius. Hal. 189-90

Wills, R.A.H., T.H. Lee, D. Graham, W.B. McGlasson, E.G. Hall. 198I. Postharvest An Introduction to the Physiology and Handling of Fruit and vegetables. New South Wales University Press. Sydney.

Yudasmara, G. A. (2015). Budidaya anggur laut (Caulerpa racemosa) melalui media tanam Rigid Quadrant Nets berbahan bambu. JST (Jurnal Sains Dan Teknologi), 3(2). doi: 10.23887/jst- undiksha.v3i2.4481

Zhou, Q. (2016). Influence of the Freezing Process on Quality Retention of Frozen Tomato Slices. The Ohio State University. 